\title{
Machinima and Ethnographic Research in Three-Dimensional Virtual Worlds
}

Débora Krischke Leitão (UFSM)

Laura Graziela Gomes (UFF)

\begin{abstract}
In this paper we propose to share our experience of ethnographic research in the virtual world Second Life. We intend to narrate our experience producing machinima the method we used to enter the field and interact with residents. The production of films from the software and or hardware of video games or other real-time $3 \mathrm{D}$ graphics programs is called machinima. Our goal here is to discuss the possibility of using machinima as a technique for obtaining, presenting and interpreting ethnographic data.
\end{abstract}

Keywords: machinima, Second Life, ethnography

\section{Resumo}

Nesse trabalho propomos relatar nossa experiência de pesquisa etnográfica no mundo virtual Second Life. Pretendemos narrar nossa experiência produzindo machinimas como forma de inserção em campo e de interação com os residentes. A produção de filmes a partir do software e/ou hardware de videogames ou outros programas gráficos $3 \mathrm{D}$ real time é chamada de machinima. Nosso objetivo aqui é discutir a possibilidade do uso de machinimas como técnica de obtenção, apresentação e interpretação de dados etnográficos.

Palavras-chave: machinima, Second Life, etnografia 


\title{
Machinima and Ethnographic Research in Three-Dimensional Virtual Worlds
}

\author{
Débora Krischke Leitão (UFSM) \\ Laura Graziela Gomes (UFF)
}

Second Life is a world that is realized in image and by image, it is a large bricolage of images and textures. From a physical and material perspective, that is to say it is made of pieces, of leftovers and remains of images. It can also be said that it is a giant visual catalog of our material civilization. Here is where certainly resides one of its most problematic meanings, from an anthropological, philosophical and even a metaphysical perspective - Second Life comes quite close to the strange story narrated in the novel The Invention of Morel, by Bioy Casares, including the disturbances that overcome the narrator, or even the "butterflies in the stomach" and sensations of horror that unsettle the characters and readers of Lovecraft's stories.

In this article, we reflect on our ethnographic practice in this virtual world, focusing above all on our action as researchers-machinimistas. We begin with a presentation of Second Life, essential for understanding the environment where our research takes place. We then address the process of constitution of machinima as technique, from the replay of the games to the production of films. Finally, we discuss the use that we have made of machinimas in our ethnographies in virtual worlds, our choices and the challenges confronted, supporting our analyses with reflections already conducted in the field of visual anthropology and hypermedia. To allow greater understanding of some technical and native terms used, we present a brief glossary at the end of the article.

\section{First approximations to the virtual world Second Life}

It is important to begin with the affirmation that Second Life is a virtual world, it is not a game. ${ }^{1}$ In operational terms, there are various servers

1 Many insist on considering it a Massively multiplayer online role-playing game (MMORPG). Nevertheless, there are quite significant differences that distance SL from a game, even from an on-line RPG, beginning with the operational and technical conditions, combined with greater complexity of 
throughout the world on which are installed the systems (data bases) that make possible the existence of this world and allow the users-residents to access it from their own equipment People access Second Life through special browsers or viewers that are not the same as those used to browse the common web. There are some pre-requisites or conditions for becoming a user of SL (the abbreviation for Second Life). First, it is important to have a powerful computer with a configuration that includes a large memory and a good quality video board, in addition to a good broad band connection (providing speed and above all stability). Second, the user must open an account - which can be free of charge or not - in the system maintained by the Linden Labs company. Upon opening your account, the user chooses and receives a generic avatar, or that is, a $3 \mathrm{D}$ creature offered by Linden Labs. One cannot enter or frequent Second Life without the mediation of one of these avatars. Upon making the first login, the user come upon her creature, generated from within the system, and must learn to handle it and deal with the environment to be able to dedicate oneself to the activities of her choice, establish contacts with other people from different parts of the world, and establish and maintain relationships with them, (emotional, romantic, of friendship, etc), work, earn virtual and real money and be part of groups with a wide variety of objectives.

In sum, between having good equipment, opening an account, being able to $\log$ in, be confronted with the creature and together with it be able to explore that world until acquiring a certain command of it, as well as developing one's own plan about what they want to do or even be in that world supposes a relatively long learning process that requires time, patience and particularly the construction of a bond, that is, a connection with and affection for the avatar (Gomes, 2012). In parallel to the construction of this tie with the avatar, both the user and the avatar will have to learn to deal with the environment, and to do so the user must clearly understand the viewer's access commands, which provide access to the system that controls the entire environment, because they can be configured in many ways, leading to distinct perceptions of the environment itself. In addition, the user will need to learn a lot about Second Life, participate in blogs, forums maintained by other residents and particularly those maintained by Linden Labs, as well as

relations that are established within it, especially concerning the diversity of projects and searches for existing objectives among the residents. 
read important documents such as the TOS (terms of service) and the Jira. In sum, the user will soon find that resident is a better description than user or gamer, because to be a resident of that world supposes establishing strong ties with it. Someone who is not able to create ties to SL, is not able to become interested in the environment, and thus, winds up giving up on it.

Another important factor still related to the problem of required ties to the environment, is that the residents of Second Life are simultaneously creators of all the objects existing in this world and its main producers and consumers of content. They inhabit an environment constructed by themselves and not only by the company that owns the program. ${ }^{2}$ No one conducts or executes any activity without wanting to, or with which he or she is not in some way engaged. It is even possible to "play" in Second Life, after all, there are many RPG islands, but it is not something that defines the program and remains entirely at the criteria of groups of associated and directly interested residents who create and maintain an RPG island. At the same time, the margin of freedom to make or build something is quite large, only requiring that the resident have the technical, artistic and intellectual skills to do so.

\section{Machinima and the creation of content by the user}

In our experience with ethnographic research in the virtual world Second Life we realized that many residents, in addition to living their second lives, are engaged in the production of derived materials such as photographs and videos. These materials include both records of their experiences, such as a diary shared with their friends, as well as quite sophisticated artistic productions, shared with the world through platforms for sharing images and vid-

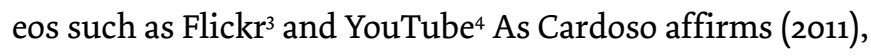

With the rise and popularization of the Internet, and the uniformization of the information in digital format, the production and sharing of images were activities that certainly presented fast and widespread acceptance by users of the global network.(Cardoso 2001:2)

\footnotetext{
2 About the importance of the construction of content by the users and their in-world learning see the article by Leitão (2012).

3 www.Flickr.com

4 www.YouTube.com
} 
Among the visual productions undertaken by residents of Second Life, videos occupy an outstanding place and fit into that which is contemporarily called "machinima." Derived from the junction of the terms machine and cinema, machinima is a "technique of making films inside virtual realities $[\ldots]$ the technique of taking a viewpoint on a virtual world, and recording that, editing it, and showing it to other people as a film " (Hancock \& Ingram 2007:10).

It thus involves the production of films based on videogame software and or hardware, virtual worlds or other $3 \mathrm{D}$ graphic programs rendered in real time. Renderization is the process through which an image created from three-dimensional geometric models is "brought to life" by mathematical calculations that determine lighting, shadow, texture, depth, distance and the level of graphic detail. Thus, on an animation rendered in real time

[...] images are computed and updated on the screen at the same rate at which the objects simulated might move in the real world. Real-time animation allows dynamic involvement by the user because the computer can accept and incorporate keystrokes or controller movements as it is drawing the next image in the animation sequence. (Aiken et al 2002:441)

This type of digital cinematic production is characterized by the appropriation of a graphic platform designed for a specific purpose - for example, to play - for the production of films. In it, an already existing three-dimensional graphic space is reutilized by the user who produces films through the manipulation of space and scenery as well as $3 \mathrm{D}$ personalities.

Various authors who research the production of machinimas (Nitsche 2011, Kelland 2011, Lowood 2011) locate their origin in the technique for recording games known as replay or demoplay. This technique rose in the $1990 \mathrm{~s}$ among players of DOOM ${ }^{5}$ and Quake ${ }^{6}$ who saved their performances in the game in DEM format files to distribute them on the Internet to other players. The demo files could then be opened in the game software, allowing the player to reproduce a sequence of movements identical to that recorded by the player who recorded them. It is precisely for this reason that this technique

5 Released in 1993, DOOM is one of the best known first-person shooter (FPS) games - estimated to have been played by more than 10 million gamers.

$6 \quad$ First FPS game with 3D graphics, released in 1996. 
was also known as replay: although it did not allow playing a game over again, it allowed watching a game again.

The replays recorded by experienced and famous players were watched by other gamers as a form of entertainment, but also for "following and learning from superior players and thus improving their own play" (Lowood 2011:6). They were, thus, also a learning channel, like the contemporary tutorials in video available on the Internet. However, because they needed the game software to be visualized, the recordings of the demo or replay type were a type of art made by players for players (Kelland 2011:23). Only those who had the game installed in their computer could watch them.

The passage from replay to machinima took place in 2000, with the release of Quad God,7 a 33-minute film made in 1999 by a player based on the game Quake III. For the first time, a film could be made from a game that did not need the game software to be watched. To record the images, its creator used a VHS video camera pointed at the computer screen, generating a machinimistic digital-analog hybrid.

A key moment in the production history of machinimas was the release, in 2004, of the game The Sims 2. The first to incorporate tools in its own interface that allowed recording the game in video (Kelland, 2011), The Sims 2 became one of the most popular platforms used for the production of machinimas. Its popularity, as we will see below, was in part generated by the broad possibilities it created for players to modify the contents of the game.

The Academy of Machinima Arts \& Sciences was created in $2002,{ }^{8}$ an entity that organizes festivals and promotes awards for machinimas. In 2000, the site Machinima.com, ${ }^{9}$ was created with a channel to promote machinimas, which has been expanded to the video-sharing site YouTube, the social network site Facebook and to a series of applications for mobile devices such as cell phones and tablets. The creation of the two vehicles contributed to the consolidation of the activity that, although it remained strongly associated to amateur production, came to be more broadly recognized, even by professional animated filmmakers and producers. ${ }^{10}$

\footnotetext{
7 http://www.YouTube.com/watch?v=kLfgPHrepj4

8 http://www.machinima.org/

9 http://www.machinima.com/

10 An example of this recognition was an episode of the series South Park that combined its traditional animated technique with the use of machinima produced in the online game World of Warcraft. This
} 
We have perceived that among the public that is not familiar with online games or virtual worlds, there is frequent confusion between machinima and animated film. Although the $3 \mathrm{D}$ figures that we visualize in machinimas were originally produced through the same three-dimensional models based on polygonal meshes and vertexes, machinima is not animation. What distinguishes them, essentially, is how they are created.

As Graça (2006) shows, in her study about the work of an animator and the process of creating animated film, "to animate" means to give life, through the illusion of movement, to fixed objects. Thus, even animated films created from three-dimensional modeling programs involve the creation and construction of movement of the image by the animator. In the case of machinima, what we see is more the capturing of images that are already in movement. In this sense, a machinima is closer to the production of liveaction films, with the "live" action of real actors and the staging of a narrative in real time. According to Mazalek, the "machinima art form incorporates elements of both live performance and cinematic production. Machinima artists puppeteer their characters inside real-time, $3 \mathrm{D}$ game engines and edit the captured sequences into linear digital films " (Mazalek 2011:92).

And if a machinima, as finalized production, is similar in appearance to animation, it is distinguished from it by its form of production, traditional film, as indicated by Manovich (2011b), although in appearance it is distant from animation, in its form of production that is increasingly closer to it:

Films and cartoons were produced completely differently, and it was easy to tell their visual languages apart. Today, the situation is different. Softwarization of all areas of moving image production created a common pool of techniques that can be used regardless of whether one is creating motion graphics for television, a narrative feature, an animated feature, or a music video. (Manovich 2011b:73)

Contrary to the production model for animated film and of traditional live action film, in the case of machinima, the technical apparatus used are much more simple. As we said before, it involves the reuse of digital tools software that provide real-time ${ }_{3} \mathrm{D}$ graphics - which already exist, and which in most cases can be used with a relatively cheap hardware configuration, if

episode, «Make Love not Warcraft», was exhibited in 2006 and is available at http://www.southparkstudios. com/full-episodes/s1oeo8-make-love-not-warcraft. 
compared to that needed for the production of professional animated films. An important characteristic of machinimas is that they can be produced from domestic, non-professional computers. Very low budget amateur productions, machinimas would be a type of creation characteristic of our time, in which the user - player - becomes an active content producer.

Burns (2008) suggested the use of the term produser to understand the contemporary plasmation between the figures of the user and content producer, indicating the inadequacy of the traditional producer-distributorconsumer chain, which is typical of the industrial mode of production. This perspective also comes close to what Jenkins (2009) calls the culture of convergence: amateurs producing content and distributing it on the Internet. In Brazil, Gomes' (2007) analysis of the phenomenon of fansites was pioneer in demonstrating how consumer-spectators of the major media actively appropriated their content, re-signifying and transforming it.

Three-dimensional online environments, such as a virtual world, present characteristics favorable to that model of action according to Manovich (2011a), given that the repeated interaction with the computer operates the transformation from spectator to user:

[...] suddenly the image is frozen, menus and icons appear and the spectator is obliged to act; to make decisions, to click, to push buttons. [...] What at a given moment was a fictional universe becomes a set of buttons calling for action. (Manovich 2011a: 273)

Because it involves the use of games for the production of films, the activity of the gamers is not always limited to capturing images. The history of production of machinimas is intimately linked to the action of the modders, users who create modifications for various digital games, frequently making them available on-line to other players. One of the most active communities in terms of moddings was, without a doubt, that of the players of the simulator The Sims 2. Since the release of the game, users from throughout the world have been engaged in the production of extra content that, thanks to the flexibility of the software, could be incorporated to the game. The content produced by amateurs, new and or customized, included "[...]cosmetic changes (new 'skins' for avatars, models, textures, etc.) and add-ons to 'total conversions' (essentially wholly new games)” (Lowood 2006:30). Between 
2004 and 2007 a large number of free distribution sites of customized content for The Sims 2 surged on the web landscape, ${ }^{11}$ and some modders became true celebrities in the world of games.

Aware of the desire for customization by the part of game consumers, many companies, according to Picard (2006) and Lowood (2006), began to provide the source code for their games and even include tools for modification for download, often, soon after the release of the games themselves. These modification tools, already perceiving the intense participation of the producers of machinimas, include both alterations in the visualization of the game, such as camera angle and zoom as well as the possibility of providing new movements/animations to the bodies of the characters, and even new forms of lip movements that emulate a "speech" effect and facilitate later synchronization with dialogs recorded outside the game.

A polemic that grew around the action of the modders at this time was similar to one still present today among groups of producers of machinimas: the question of copyrights. It is frequently affirmed that machinima producers do not have the right to explore their work commercially (Berkeley 2006:70), given that they appropriated the machnimas from programs and objects created by others, and are thus derived materials. In the scenario of modding of The Sims 2 game, some paid-content sites arose but users who defended open and free content denounced the paid sites for infringing on the copyright policy of Eletronic Arts, the game creator.

Although the policies of game creating companies had at first been relatively tolerant in relation to the action of the modders, in recent years there has been a change of procedure. The interface for the Sims 3 game, released in 2009, has greater options for customization, such as uploading textures, but its code is not as flexible as the previous version, impeding the creation and incorporation of new objects and animations. For this reason, three years after the release of the new version, many fans and players still reject The Sims 3 and use version 2 of the game, which has less graphic detail but is more open to changes.

In the game Halo, produced by Microsoft and much used for modifications and production of machinimas, there was also a "toughening" given

11 The most active of these is certainly the ModTheSims 2, which is still in activity at http://www. modthesims.info/ 
that the "development of a Halo fan mod called "Halogen," was recently terminated, claiming that using ideas and designs from the Halo universe infringes on the intellectual property" (Picard, 2006, p.4).

In the case of Second Life, given that an essential characteristic of the platform is the fact that $99 \%$ of its content is produced by users (Ondrejka, 2005), the question of copyrights currently concerns less a dispute between Linden Labs and the residents and more a dispute among residents themselves. The machinimas produced in SL usually make use of objects, sceneries, animations and avatars created by many different residents. They can include both items that were distributed free of charge as well as items purchased by the author of the machinima, for example, the clothes, hair and skin textures of their avatar. Thus, to create a video in Second Life always involves not only reusing the platform for another purpose but also incorporating a series of someone else's creations in one's own creation.

Residents certainly deal with this issue in different ways. Some content producers who commercialize their creations in Second Life define and publicize their intellectual property policies. Eshi Otawara, who is a painter outside of Second Life and owner of a clothing and shoe store in the platform, explained these limits in the profile of her avatar:

ALL of the Second Life works by Eshi Otawara/Irena Morris are licensed under Creative Commons Attribution-Noncommercial-No Derivative Works 3.o Unported License. Please familiarize yourself with the rules of the game before putting your signature on your screenshot of my work. Thanks. (information found on the public profile of the avatar Eshi Otawara, obtained in March 2011)

Thus, the content created by Eshi, as we see above, cannot be used by third parties for commercial purposes, cannot be modified in derived creations and the name of the author must always be informed.

Some creators of fictional machinimas indicate, in the credits for their videos, all of the authors whose content was incorporated, generating immense lists of credits in short films. The adaptation of Dagon, a short story by H.P. Lovecraft, by the avatar Lainy Voom, ${ }^{12}$ for example, is a video of about nine minutes: eight minutes involve the film, and one minute is dedicated to

12 http://www.YouTube.com/watch?v=CMOHpuxFbmo 
the credits. Other machinimistas, such as Rose Borchovski ${ }^{13}$ and Bryn Oh, ${ }^{14}$ in addition to film, construct artistic installations in Second Life, thus producing most of the content presented in their films.

In most of the films produced from Second Life, however, in the film credits we only see the name of the places where the video was filmed and or that of the avatars who participated in them directly - acting. In this case we are speaking of machinimas of more amateur production than those whose authors we mentioned above, who are recognized as artists and filmmakers in Second Life. The machinima technique can be used for the production of fictional films, based on an original screenplay or an adaptation of literary and cinematographic works, but in quantitative terms, what we see is the broad use of the machinima to document moments lived in the platform. Public events are filmed by the residents, but also daily experiences and moments considered to be emblematic in the life history of the avatars, such as weddings ${ }^{15}$ and births. ${ }^{16}$ Another frequent use for the machinimas is the production of advertising, tutorials or videologs. ${ }^{17}$

Lowood (2011) suggests that we think of the machinimas not only as a technique for producing and obtaining images for the construction of narratives of content that is outside the virtual worlds, but also as a form of historic record of these digital games and virtual worlds. Machinimas thus create, "[...] historical documentation that captures aspects of the spaces, events, and activities through the lens of a player's view of the game world" (Lowood 2011:4), in addition to documenting technical aspects of the software, the platform, which having its own historicity, can be transformed with the passing of years or even disappear. An exemplary video in this sense is "EA-Land: The Final Countdown, ${ }^{18}$ " which registers the final minutes in the life of a virtual world closed in August 2008. The video was made by a resident and it is her emotional voice that we hear offering thanks and saying goodbye.

In terms of Second Life, the machinimas produced by residents function

\footnotetext{
13 http://www.YouTube.com/user/ZebraZoe

14 http://www.YouTube.com/user/BrynOh

15 see, for example: http://www.YouTube.com/watch?v=2L_CopK79_M

16 see, for example: http://www.YouTube.com/watch?v=P58y63Ujj14

17 see, for example: http://www.YouTube.com/watch?v=pjHofse3W14\&

18 http://www.YouTube.com/watch?v=IT5lLTWxoL4
} 
as a way of documenting the history of this virtual world and its different epochs. A video realized by James Linden, for example, portrays what the avatars were like - at the time "primitars" - in 2001, during the period of tests of the so-called Linden World, which later would come to be re-baptized as Second Life. ${ }^{19}$ Even videos considered by the residents to be fictional, however, present images that allow this historic preservation and recording of different moments of virtual worlds, serving as a documentation of the transformation that took place there in terms of technical configurations, aesthetic preferences and modes of sociality.

\section{Machinima Production and ethnographic practice in virtual worlds}

Based on contact with the machinima technology and of the recognition of its importance in virtual worlds, we began to conduct video experiments as part of our ethnographic research in Second Life. Conducting research in virtual worlds, we are immersed in an environment in which the visual stimuli are central. Not that hearing is not important, but it does not have the same magnitude as the visual and the written. In any case, they are listenings that are very different from those practiced by the anthropologist in RL, because they have music as an omnipresent element, whether the environmental music of the island visited, or the eventual music brought by the avatars when they activate their own voices, in addition, of course, to the conversations that can also be had by voice among the avatars, at certain moments.

Curiously, voice is a component that is not highly used, that is, its use is restricted. There is a technical reason for this (which is always invoked as a justification for not activating voice) but there is also a social reason, because it is the most "human" element of the entire situation on the screen. Introducing the human voice into the interaction taints the fictional world, the fantasy or the dream that the user is constructing with the avatar, at the same time in which it can betray the image or the reputation of its avatar in that context. Voice is problematic, because it introduces realistic data, which is an abrupt infiltration of real life into Second Life. Thus, the use of voice can be perceived by the residents as a break from the immersion. As

19 The video, available at http://www.YouTube.com/watch? $\mathrm{v}=\mathrm{uK} 3 \mathrm{x}_{3} \mathrm{FNlleU}$, was filmed in 2001, but made public by the avatar Torley Linden in 2006. 
suggested by Manovich (2001), in virtual worlds, the effects of the immersion of materiality are achieved above all through the construction and deconstruction of images. ${ }^{20}$

Faced with an object of study based, therefore, on the image, we could not fail to produce images and reflect on their incorporation in the construction of anthropological knowledge. As Feldman Bianco affirmed (1994),

[...] the emphasis on written text relegated to a marginal position and hides the fact that the practice of anthropological research also implies, on one hand, the production of visual artifacts as documents that are constitutive of research; and on the other, not only on the elaboration of written texts but also in the production of visual ethnographies." (Feldman Bianco 1994:55-56).

Contemporarily, therefore, there has been a positive proliferation of anthropological work that incorporates image. If in the past the recourse to photography or video was understood as a freezing of the culture studied, with the methodological and theoretical transformations in conducting anthropology, we are distanced from a positivist ingenuity that considers the ethnographic text as a "portrait of the real" and the image as its copy (Eckert and Rocha 2008). Today, both image and text are perceived as analytical and interpretive routes based on the experience of the alterity mediated, in the first place, by the very subjectivity of the researcher. The production of visual narratives, thus

[...] does not substitute or facilitate the effort at dense description, to the contrary, it transports the effort to translate meanings, of the challenges of writing to the exploration of the limits of the audiovisual aesthetic, expanding the cinematographic imagination of the authors, characters and spectators in the discovery of new aesthetic universes and new theoretical questions. (Devos and Vedana 2010: 6)

In the case of Second Life, by producing machinimas we are producing images based on digital and synthetic images. In a certain way, we can say that we are producing images from images produced by others, which, in turn, are the fruit of the appropriation of a myriad of other images produced by other others. The production of machinimas in ethnographic research

20 About this, see http://www.YouTube.com/watch?v=W3oTUTNyyB4\& 
is not different than the production of machinimas by the part of the other residents of the virtual worlds in the sense of it being a bricolage that would always involve a large number of mediators.

We believe, therefore, that the production of machinimas can be used not only as a means for the publication and promotion of data, but also as a method for conducting fieldwork (MacDougall, 1994). As Piault also suggests,

[...] for anthropology, cinema and various audiovisual methods are both instruments of observation, instruments of transcription and interpretation of different social realities as well as instruments for the illustration and promotion of research. (Piault 1994:63).

Thus, we have made use of machinimas to document situations lived and observed during the fieldwork, as a type of field notes in movement. Many of our records, whose broad promotion was impeded for ethical reasons that will be addressed below, became work documents with strong mnemotechnical value. They came to serve as triggers for memory, through which the researcher could be transported to that "time of immersion," and recover the memory of that instant, and describe it through another recording process. Given this possibility, an important step in methodological terms was the classification of this material into topics or themes, as a function of the memories and recollections to which they refer with greater emphasis.

Even though these registrations cannot be published, by watching them sometime later, they allow accessing the memory of those instants and highlight what took place that was important, in order to add to or not pertinent information about that moment of immersion. Another important item in the classification of the field records in movement are the parties, and since there is quite a bit of material about them, this allows making a historic reflection on sociability in SL in relation to various important aspects, from the appearance of the avatars, to the decoration of the environments where these parties were held and also the forms of interaction that they generated, the subjects of the conversations and dialogs that appear in the local-chat where they all participate in the form of a large collective conversation.

Recalling the proposal by De France (1998), the record of this field material in the form of machinima allows, for example, a later return to the material, including the possibility of watching it once again in slow motion. For the analysis of the techniques of the body, gesture and performance, this 
resource could be interesting, because it allows a more careful look at the details, without losing sight of the totality lived as register, and the decomposition of movement that can be analyzed in greater detail.

In addition, for the researcher of virtual worlds, the visual registrations are also fundamental because we are speaking of a world where metamorphosis is a categorical imperative. And this holds true both for the environment, such as islands, landscapes - which appear and disappear from one hour to the next - and even to the avatars, which, in a matter of seconds transform and change their accessories without a bit of awkwardness, completely altering their appearance. For the researcher, many of these events are unique moments that he knows that he will not be able to witness once again. To conduct research in SL without being able to visually record this world is practically impossible, making it very difficult to describe this world or even to be able to explain it to non-users and non-residents.

Although at times we think of this first category of machinimas that we described until now as a type of "field notes in movement," we do not share the naive illusion that they are raw materials. Certainly, the act of filming, even without a later editing process, involves an interpretive effort by the part of the researcher. In the case of the researcher-avatar, he must chose positions and distancing from the camera, chose options for lighting and graphic details in the viewer's interface and chose where to leave his avatar during the filming process. All these choices also concern the technical learning needed to live in and conduct research in virtual worlds.

For this reason, a second category of machinimas that we have produced are those that we call "visual experiments." Their objective is learning and they allow us to better understand, through practice, graphic tools available in Second Life (lighting, depth of field, shadows, camera movement, rendering resources) and those offered by software for capturing and editing images, production of synthetic voices and audio editing, $3 \mathrm{D}$ modeling, and others. As Rouch suggested (2003a), it is imperative to learn the technique, even if films produced by anthropologists may be technically inferior to those made by professionals, or, in the case of SL, by more experienced residents.

If for Cardoso de Oliveira (1998), the work of the RL anthropologist consists in looking, listening and writing, for the SL anthropologist, this order is profoundly changed, because in this context the look, the sense of sight, has vast importance. To look in Second Life means to look at the many different 
forms, but always with vision mediated by the commands of the browser, that is, by the camera devices that it contains. The camera-eye contains the graphic interface itself, which is also a mediator of interpretation. In this situation, the anthropologist must know how to use this navigation tool with relative competence to be able to position the camera and look, see everything that is important and recognize the details that are of interest to her work.

In a third category we locate the machinimas that we consider to be more experimental in a more epistemological than technical sense. Functioning as a type of digital collage, they allow combining interpretations of situations from the field with excerpts from anthropological literature, and various other sources of information - websites, films, music, etc. These videos, which to some degree function not only as a register but also as instruments for presentation of research data, are conceived by us as a visible construction of our own thinking and interpretation. In all these categories we have invariably included the presence of our avatars, given that they are the fundamental mediators in the interplay of eye-camera-interface-avatar. In the case of the latter, however, our presence becomes more explicit in the stitching of the layers of interpretation by means of the deliberate effort at editing and of frequent use of our own voice. The question of narration has for a number of decades been a polemic in the realm of imagetic ethnographic productions. The discourse of the director in the narration, as Rouch (2003a) indicates, has at times been explored as an objective and scientific description, but should be subjective and active in the sense of explaining her position and interpretive bias.

Our objective, when we inserted ourselves into the machinimas in our own voice, was not to dissimulate authorship through a "narration in the voice of god," as suggested by Menezes (2007) about Rouch. To the contrary, we sought through this resource to establish, in the machinima itself, the voice of the anthropologist, trying to establish ties between the images captured, the theory and our analytical efforts. Although we sought to indicate a network of possibilities, in the terms of Caiuby (2008), we certainly did not fail to consider that this unleashing of ideas, in video, would be conducted to a large degree by those who watch, given that in the machinima

[...] what is important is the principle of discovery based on the unleashing of images, which are linked by their proximity or resonance. It is the receptor of the images (and not the author, as occurs in text) who constructs the 
relationship between one image and another. The author is certainly present, presenting the theme, but it is up to the person watching the film to create the predicates. It is the spectator who discovers the connections between one network of possibilities structured by the author. (Caiuby 2008: 464)

Although their production processes presents challenges and innovations, we believe that in general the machnimas adopt a quite traditional narrative form, both those made by other residents as well as some of our own. For this reason we are conducting experiments with interactive videos, making use of the simple and accessible technology provided by the sharing sites, so that a single video can be "linked" to various others, forming a directed hypertextual narrative, but one that is reasonably flexible to a viewer's choices. As Eckert and Rocha affirm (2008),

Face à l'environnement déterritorialisé de l'hypertexte, les anciennes pratiques d'écritures dont sont porteurs les anthropologues et les micro-territoires de leurs œuvres ethnographiques (qui leur confèrent le statut d'auteurs) subissent de nouvelles contraintes, que quelques-uns désignent sous le terme "d'ingénierie d'auteur ». Celle-ci s'appuie sur la génération et la manipulation d'informations et de données digitales, selon des modèles de configurations visuelles (lettres, mots, textes), dans des archives enregistrées et communiquées conformément à des procédures déterminées de montage et d'association d’idées, incluant le lecteur comme coauteur. (Eckert e Rocha 2008, s/p),

Although the advent of the Internet creates the possibility for multiple, varied and unpredictable audiences, a fundamental question to be considered is exactly "who is watching?" who is our reader/co-author? Reporting on his possible responses to the question "for whom do I film" Rouch (2003a) said that, in the first place, for oneself, for the pleasure itself that the activity provides. Second, he says he films for those who participate in his films:

Film is the only means I have to show someone else how I see him. For me, after the pleasure of the ciné-trance in shooting and editing, my first public is the other, those whom I've filmed. [...] The situation is clearly this: the anthropologist has at his disposal the only tool (the participating camera) that offers him the extraordinary possibility of direct communication with the group he studies - the film he has made about them. (Rouch 2003a: 43)

Agreeing with Rouch, we believe that those who first navigate through 
our machinimas are the very residents of Second Life, and our films are our way of showing how they are seen by us and of establishing communication. As we said at the beginning, the residents of this virtual world are active producers and consumers of content about SL, not only in the platform but also in other locations of cyberspace encompassed by the sociability of SL, such as Flickr and YouTube. Aware that our films will not be watched only by those specific subjects who are portrayed in them, but possibly by a large number of their contemporaries who are also residents of Second Life, a series of ethical questions is raised.

Concerning the authorship of objects and scenarios, as we discussed before, it is inevitable that a wide variety of objects and different creators wind up being registered in our videos. To require credits for each element that composes the photo of a landscape or of an avatar becomes a paradox. It would be the same as requiring that the avatars not use anything that they themselves did not make. But this occurs and there are users and residents that rebel against photographs or even films, requiring that the images of their avatars not be promoted or publicized on any site or even social network, Flickr, etc. Unfortunately, most of this material cannot be published, precisely because it contains avatars, many of them still active and which refuse to authorize the publication of scenes that contain their image or objects that they created, even for an academic project.

This article does not intend to consider the merit of the idiosyncrasies that guide the subjectivities and the "hearts and minds" of the avatars in this environment, but it is necessary to emphasize that the concept of personal identity of the avatar is very strong in Second Life and that, in many cases, there is a desire to maintain anonymity. We are not making a reference here only to the real life identity of the person who controls the avatar, but the identity of the avatar itself. The avatars in Second Life have a network of friends and acquaintances, a reputation, a trajectory and life history, habits and groups with which they identify and in some cases, romantic and family relationships internal to the virtual world. In this sense, to portray the image of an avatar in a certain location or situation, without proper authorization, could be considered an act that counters the desire for anonymity, even if there is no reference to the person who controls the avatar.

To deal with this situation, we have used a few different strategies. One of them has been the creation of performances, inspired in what we observe, 
with our own avatars, so that it is possible to film them and publish them, given that there is no exhibition of avatars of third parties, and their own environments will be used as scenery for the filming. In this direction, 21 experiments were already conducted and published that concern a number of different themes or issues about which we are writing. ${ }^{21}$ Some of these experiments were used as a base for a recently published article about neoteny in Second Life (Gomes, 2012).

Another strategy that has been used by us is the production of machinimas in conjunction with the residents. Although we film through our own eye-camera-interface-avatar, and we make a first edition on our own, we make available first edits of our films for the people involved in them. Through tools available on the interface of sites like YouTube and Flickr, these first versions can remain "secret", and can only be seen by those who have the link or whose name (that of the avatar) is marked on the image. In this way we have, in the first place, the opportunity to determine if they agree with the material produced and with its broad distribution. Moreover, this resource allows for the residents to give their opinion about the montage, editing, sound track etc. This feedback has been considered in the reworking of the video, before its publication in an open fashion.

This final experience has required that the original archives of the films be reserved, in addition to the edited videos, at least until the finalization of this process of construction of the machinima. In technical terms, the conservation of these raw digital archives involves the use of large quantities of space on a hard drive. A file of two minutes of video captured from the Second Life interface, recorded in high definition, occupies about two gigabytes of disc space, which means that we must use many external HDs, and avoid using the hard drives of our computers so that they are available for emergency recordings - which also occupy the same impressive amount of space on disk. As we saw previously, in Second Life, the rhythm of events is quite accelerated, and there is often no time to wait for the transfer of files or to clean disk space. It is necessary to go to the field properly equipped in advance, with your film program activated, and with lots of gigabytes available for recording.

21 These experiments can be seen in the blog of Laura Graziela Gomes, available at http:// secondanthropology.blogspot.com.br| 
These technical concerns about hardware - the issue of disc space, the quality of the video board or of the speed and stability of the Internet connection - and concerning the software - the speed in using the program for capturing and in the editing programs - does not only concern that which is dedicated to research in virtual worlds, but is a constant issue among most residents. Many of them, as we said, also produce films, and it is interesting to perceive how in many situations we have been incorporated, as avatar researchers, in the images produced by other residents. ${ }^{22}$ As Rouch suggested (2003a and 2003b), in his proposal for a shared anthropology,

Knowledge is no longer a stolen secret, devoured in the Western temples of knowledge; it is the result of an endless quest where ethnographers and those whom they study meet on a path that some of us now call "shared anthropology." (Rouch 2003b: 101)

The machinimas that we consider can be made public have been broadly publicized to the residents of SL, by means of YouTube, Flickr and blogs, ${ }^{23}$ but also inworld, and have thus been commented upon and criticized by the residents. The production of machinimas proved to be a productive and pleasurable way of entering the field and interacting with other Second Life residents. Thus, the production of machinimas, in addition to being a technical necessity for recording and cataloging, is an effective research tool: they generate new social relations, new research data, exchanges of points of view and especially new processes for learning about social and cultural aspects of Second Life.

\section{Final Considerations}

The Second Life user and resident is a compulsive reader-spectator, therefore, a compulsive creator-seeker of content, and even when immersed with his avatar and interacting in that world he may, as a human, have various other computer screens open, and be reading and looking at something that he can use and bring to the world. Thus, an anthropologist who wants to study this

\footnotetext{
22 For example, in the machinimas available at http://youtu.be/pcy22Nj2uGo e http://youtu.be/ GlrmYZe6hRA.

23 http://machinimafieldnotes.blogspot.com e http:/|secondanthropology.blogspot.com.br/
} 
world should share or be quite sensitive to this profile, and in a certain way be an appreciator and consumer of the elements that constitute the core of the lifestyle of this world. It is not possible to conduct ethnography in this world without becoming an inhabitant in it, even if provisorily, to participate in its culture especially by sharing the visual matrixes upon which it is constituted, to know how to identify the visual references that serve as inspiration for the construction of landscapes and of the very environments in which the actions or the drama of the avatars take place.

For all users and residents, one of the most important activities and occupations in Second Life, that which most attracts everyone's interest and contributes to the construction of a personal and collective tie with the environment are the activities for visual recording, in order, photography and more recently the machinimas. Photographs and machinimas have become an important language in this environment, of the modes of narrating it and as a specific form of communication practiced by the residents themselves for communicating among themselves and with those "outside." For researchers, they are both materials that it is important to work with, and through which we construct our knowledge about these worlds. Especially, in the case of anthropology, the visual records made during our immersible observations contribute considerably to reconsider this essential category, which is fieldwork.

\section{Glossary}

Camera: Allows controlling, using the keyboard or mouse, the point of view in the three-dimensional world. Experimenting with the commands it is possible to visualize objects, avatars and landscapes from any angle or distance desired.

DOF: Depth of field, simulates the photographic effect of the same name, allowing the "lens" to focus on a specific object, removing focus on the rest. This effect was first introduced in an experimental manner in Second Life, and was effectively incorporated to the viewer in 2011.

Flickr: Platform for sharing images created in 2004. Its use, by the residents of Second Life, goes beyond the simple functionality of an online photo album, acquiring characteristics of a social network: the residents post images daily, and mutually comment and favor, they create thematic discussion groups and mark their friends (who are also users of the platform) to 
publicize meetings and adventures shared inworld.

IM: Instant Message, allows the residents to establish private conversations with each other. Contrary to an open chat, these conversations will not be seen by the other residents who are not involved. One can send an instant message both to a resident whose avatar is effectively present in the same location or to one who is at a distance. Not being seen by the others, this form of communication is at times understood as similar to whispering. Its use is justified both by the effects of maintaining a private conversation - it allows keeping a secret - and to not disturb other residents with conversations that are not of interest to those involved in an open chat.

Inworld: Indicates actions and interactions that take place inside the virtual world, within Second Life.

Jira: Forums maintained by Linden Labs and frequented by Second Life residents for the purpose of bug tracking, issue tracking, and project management, allowing exchanging information and feedback among residents and programmers.

Meshes: Polygonal grids composed of vertices that function as a type of skeleton for the three dimensional objects. Once sculpted in programs such as 3Dsmax, Maya, Milkshape 3D and Blender, the meshes can be texturized and have a series of their properties altered. For quite some time, this is the technology used for modeling ${ }_{3} \mathrm{D}$ objects, scenarios and personalities of digital games. Open Chat: Window for public conversation in Second Life. It can be accessed by residents who are in the same region.

RPG: Game for interpreting characters. In terms of Second Life, at times it is referred to by the residents only as RP or $\mathrm{R} / \mathrm{P}$. This particularity can be understood if we consider the request, by the part of users, that SL not be understood as a game. There are places for RP with various fantasy or realistic themes in Second Life, such as vampires, post-apocalyptic worlds, science fiction, specific historic periods or contemporary Brazilian favelas.

TOS: Terms of service, rules with which the user must agree to enter a platform. They concern some rules of co-existence, privacy and copyright. They are periodically altered as a function of the demands of users and or the interest of the company. They can be accessed in: $<$ http://secondlife.com/corporate/tos.php >

Viewer: Program for visualization that provides access to a virtual world, similar to an internet navigator. It is frequently updated. There is the official 
viewer from Linden Labs and a series of alternative viewers, created or modified by users who, although they do not have the support of Linden Labs, have its authorization to be used. Most of the residents alternate using different viewers, according to the activities that they intend to execute in the world. Voice: A complement introduced in Second Life to allow voice conversation. When the user speaks, the lips of its avatar move in a synchronized manner. Even if this has met resistance by many users who allege that the "human" voice compromises the immersion, it is a resource that is quite often used in the production of machinimas.

Windlight: effects for rendering graphics related to atmospheric configurations of Second Life, such as lighting, clouds, fog, distance of visibility, sky colors, solar position and others. Its parameters are manipulated by residents to obtain the desired illumination, particularly concerning the capture of videos or static images.

YouTube: platform for sharing online videos created in 2005 and used by the residents of Second Life for publication of machinimas.

\section{Bibliographic References}

AIKEN, Peter et al. 2002. Microsoft computer dictionary. Washington: Microsoft Press.

ANDERSON, Benedict. 2005.Comunidades imaginadas. Lisboa: Edições 70.

AU, Wagner. 2008. Os bastidores do Second Life. São Paulo: Ideia \& Ação.

BIANCO, Bela Feldman. 1994 "Antropologia e cinema: questões de linguagem”. In: P. Monte-Mór; J. Parente (orgs), Cinema e antropologia, horizontes e caminhos da antropologia visual. Rio de Janeiro: Interior Produções, pp. 51-79.

BURNS, Alex. 2008. Blogs, Wikipedia, Second Life and beyond. New York: Peter Land.

CAIUBY NOVAES, Sylvia. 2008. "Imagem, magia e imaginação". Mana. Estudos de Antropologia Social, 14(2): 455-475.

CARDOSO, Bruno de Vasconcelos. 2011. "Intimidades (de)flagradas: real, falso e ficção no videovoyeurismo". IX RAM. Mimeo.

CARDOSO DE OLIVEIRA, Roberto. 1998. O trabalho do antropólogo. Brasília/

São Paulo: Paralelo Quinze/ Editora da Unesp.

DE FRANCE, Claudine. 1998. Cinema e antropologia. Campinas: Ed. da 
Unicamp.

DEVOS, Rafael e VEDANA, Viviane. 2010. "Do audiovisual à hipermídia”. Antropologia em Primeira Mão, 120. Retrieved November 17, 2011, from 〈http://apm.ufsc.br/files/2012/11/120-APM-2010-DEVOS-VEDANA.pdf〉

GOMES, Laura Graziela. 2012. "Pequenos mundos gigantes: neotenia e transdução no Second Life”. In: L. Barbosa (org.), Juventude e gerações no Brasil contemporâneo. Porto Alegre: Editora Sulina. pp. 121-155.

GRAÇA, Marina Estela. 2006. Entre o olhar e o gesto: elementos para uma poética da imagem animada. São Paulo: Editora SENAC São Paulo.

HANCOCK, Hugh; INGRAM, Johnnie. 2007. Machinima for Dummies. Hoboken: Wiley.

JENKINS, Henry. 2009. Cultura da convergência. São Paulo: Aleph.

KELLAND, Matt. 2011. "From game mod to low-budget film: the evolution of Machinima”. In: H. Lowood; M. Nitsche (orgs.), The Machinima reader. Cambridge: The MIT Press. pp. 23-36

LEITÃO, Débora Krischke. 2012. "Entre primitivos e malhas poligonais: modos de fazer, saber e aprender no mundo virtual Second Life." Revista Horizontes Antropológicos, 38: 255-285.

LOWOOD, Henry. 2011. "Video capture: Machinima, documentation, and the history of virtual worlds". In: H. Lowood e M. Nitsche (orgs.), The machinima reader. Cambridge: The MIT Press. pp. 3-22

LOWOOD, Henry. 2006. "High-performance play: the making of machinima". Journal of Media Practice, 7(1): 25-42.

MACDOUGALL, David. 1994 "Mas afinal, existe realmente uma antropologia visual?”. In: Catálogo II Mostra Internacional do filme etnográfico. Rio de Janeiro.

MANOVICH, Lev. 2011. "Image future”. In: H. Lowood; M. Nitsche (orgs.), The machinima reader. Cambridge: The MIT Press. pp. 73-90

MANOVICH, Lev. 2011a. El lenguage de los nuevos medios de comunicacion. Barcelona: Paidós.

MAZALEK, Ali. 2011. “Tangible narratives: emerging interfaces for digital storytelling and machinima”. In: H. Lowood; M. Nitsche (orgs.), The machinima reader. Cambridge: The MIT Press. pp. 91-110

MENEZES, Paulo. 2007. "Les maîtres fous, de Jean Rouch: questões epistemológicas da relação entre cinema documental e produção de conhecimento”. RBCS, 22(63): p.81-91. 
NITSCHE , Michael. 2011. “Machinima as media”. In: H. Lowood; M. Nitsche (orgs.), The machinima reader. Cambridge: The MIT Press. pp. 113-126. ONDREJKA, Corry. 2005. "Escaping the gilded cage”. New York Law School Review, 49(2). Retrieved December 10, 2011, from <http://www.nyls.edu/ user_files/1/2/23/144/216/217/218/escapefinal.pdf >.

PIAULT, Marc-Henri. 1994. “Antropologia e cinema”. In: Catálogo II Mostra Internacional do Filme Etnográfico. Rio de Janeiro.

PICARD, Martin. 2006. “Machinima: video game as an art form?” Proceedings of Canadian Games Study Association Symposium. Montreal.

ROCHA, Ana Luiza Carvalho da; ECKERT, Cornelia. 2008a. "Etnografia: saberes e práticas" Iluminuras Revista Eletrônica do BIEV/PPGAS/UFRGS, 31. Retrieved March 22, 2012, from <http:/|seer.ufrgs.br/iluminuras/article/ view/9301>

ROCHA, Ana Luiza Carvalho da; ECKERT, Cornelia. 2008b. 'L' anthropologie dans les interfaces du monde de l'hypertexte”. Ethnographiques.org, 15. Retrieved March 22, 2012, from <http:/|www.ethnographiques.org/2008/ Carvalho-da-Rocha,Eckert>

ROUCH, Jean. 2003a. “The camera man”. In: S. Field, Ciné-Ethnography.

Minneapolis: University of Minnesota Press. pp. 29-49.

ROUCH, Jean. 2003b. “On the vicissitudes of the self”. In: S. Feld (org.), Cinéethnography. Minneapolis: University of Minnesota Press. pp. 87-101. SIMONDON, Gilbert. 2008. El modo de existencia de los objetos técnicos. Buenos Aires: Prometeo Libros.

\section{About the authors}

Débora Krischke Leitão is professor in the department of social sciences and the graduate program in social sciences at the Federal University at Santa Maria. She is organizer of the book Antropologia e Consumo (AGE, 2006) , co-author of the book Antropologia (EdUFMT, 2009) and author of various articles and book chapters. Member of the Interdisciplinary Group for Cyberculture Studies. < http://dgp.cnpq.br/buscaoperacional/detalhegrupo. jsp?grupo=0327703ENZ8GP1 >

Email: deborakl@gmail.com Rua Acadêmico Rigoberto Duarte, 15, apto. 503. Santa Maria. 97.060-030 Rio Grande do Sul 
Laura Graziela Gomes is professor in the department of anthropology and the graduate program in anthropology at the Federal Fluminense University. She is author of Novela e Sociedade no Brasil (EdUFF, 1998) and of various articles and book chapters. Member of the Interdisciplinary Group for Cyberculture Studies. < http://dgp.cnpq.br/buscaoperacional/detalhegrupo. jsp?grupo=0327703ENZ8GP1 >

Email: lauragraziela@gmail.com

Praia João Caetano, 75/1201, Ingá, Niterói, 24.210-405

Rio de Janeiro

Translated by Jeffrey Hoff

Article received April 30, 2012, approved June 30, 2012 